\title{
Birgitte Eskildsen \\ Paradise Lost: Stormen på Galilæas Sø - en bibelsk fortælling om brud på sprogets dybde-grammatiske regler
}

Undergangsvisionen, jeg behandler i dette essay, vedrører et brud i den kristne bibels Kristus-vision på en dybde-grammatisk regel i sproget. Nemlig den regel, at der i enhver forandringsproces er givet et subjekt, som dybest set forbliver uforandret. En regel, hvis fremsættelse Justus Hartnack i Strejftog i filosofien tilskriver Aristoteles, men for hvis opdagelse han akkrediterer Heraklit og udsagnet "Man kan ikke to gange gå ned i den samme flod." Den traditionelle tolkning af dette udsagn som om 'alting flyder' er ifølge Hartnack forkert, fordi den negerer kernebegrebet 'flod' og hermed sætningens dybde-grammatiske subjekt: På grund af en misforståelse af negationen "ikke" i udsagnet overser man, at udtrykket "den samme" tilkendegiver det faktum, at floden fortsat består. For nok strømmer der uafbrudt nyt vand til floden - og den er derfor aldrig helt den samme i dag som i går - men samtidig forbliver floden netop flod, fordi den hele tiden tilføres nyt (Hartnack 1996: 18-19).

Jeg vil nedenfor udfolde fire sammenhængende teser: For det første at der i Det Nye Testamentes ældste evangelium, Markusevangeliet (ca. 70-80 e.Kr.), opdages en dybde-grammatisk regel identisk med det princip, Heraklit kalder for logos. Dette sker i det såkaldte Lignelseskapitel i Mark. 4, hvor Jesus fortæller lignelser ved Galilæas Sø og anvender naturen som et billede på logos - på "ordet" i den danske version af den oprindeligt græske tekst. Præcis som Heraklit, for hvem naturen, fysis, og den guddommelige logos er ét.

Ved kapitlets afslutning splintres denne harmoniske referenceramme imidlertid brat, da Jesus betvinger en hvirvelstorm ude på søen og derved blotlægger et modsatningsforbold mellem natur og ånd for øjnene af sine 12 disciple. En præstation, som afføder, hvad man med et moderne udtryk kunne kalde for en eksistentiel angst iblandt dem. Den samme type genstandsløse angst, som Søren Kierkegaard i Begrebet Angest bestemmer som "noget aldeles forskjelligt fra Frygt og lignende Begreber, der referere sig til noget Bestemt" (SKS 4: 348). 
Min anden tese er i denne sammenhæng, at fortællingen om stormen på Galilæas Sø udgør den europæiske litteraturs første forsøg på en tematisering af angsten, forstået i den samme skarpe modsætning til frygten som hos Kierkegaard og i overensstemmelse med hans opfattelse af angsten som "Frihedens Virkelighed som Mulighed for Muligheden.” (SKS 4: 348).

Min tredje tese lyder i forlængelse af de to første, at det angstfremkaldende brud på harmonien mellem natur og ånd er forbundet med bruddet på en dybde-grammatisk regel i sproget, som ophæver identiteten mellem fysis og logos. Et brud, evangelisten bevidst iværksætter med henblik på visionen i Mark. 9, hvor Jesus fra Nazareth transformeres til Kristus:

Seks dage efter tog Jesus Peter og Jakob og Johannes med sig og førte dem op på et højt bjerg, hvor de var helt alene. Og han blev forvandlet for øjnene af dem, og hans klæder blev skinnende hvide, meget hvidere end nogen på jorden kan blege dem. (Mark. 9, 2-3)

Ud over klare reminiscenser af den bibelske bjergtradition, der kendes fra bl.a. Det Gamle Testamentes Mosebøger, minder omstændighederne omkring transformationen påfaldende om Hulelignelsen i Platons Staten, hvor en frigiven fanges opstigning mod dagslyset fra fængselshulens skyggeverden udlægges som et billede på sjælens vandring fra sanseverden til idéverden (Pol. 514a ff.). En verden, mennesket nærmer sig gennem theoria, der på græsk betyder 'beskuen', og som Platon i Faidros beskriver som en opstilling "på himmelens ryg", hvor den, der følger guderne, "ser selve retfærdigheden, ser besindigheden, ser viden." (Faidr. 247e).

Dette knytter an til min fjerde og sidste tese: Hvor indholdet i Jesu lignelser på centrale områder korresponderer med den såkaldte førsokratiske naturfilosofi, der opstod på Lilleasiens vestkyst, Jonien, omkring år 550 f.Kr., er transformationen udpræget 'platonisk' i bevægelsen "op på et højt bjerg" hinsides fysis. Forløbet fra lignelsestaler med naturens vækst i centrum, over betvingelsen af stormen på Galilæas Sø, til Kristus-visionen på bjergets top lader sig i dette perspektiv læse som fremskrivningen af den samme form for 'værensglemsel', som ifølge Heidegger har kendetegnet filosofien siden Platon, hvor ét værende træder frem som værens grund: først som 'idé' og siden, i kristendommen, som 'Gud', indtil Descartes satte det menneskelige 'cogito' som værens fundament. Væren negligeres til fordel for bestemmelser af det (højeste) værende og 'glemmes' i en stadig mere reduktionistisk tilsløring af betydninger og sammenhænge, hvor mennesket ikke længere har nogen egentlig kontakt med verden. 


\section{Opdagelsen af logos' dybde-grammatiske funktion}

I Mark. 4, 1-34 fremlægger Jesus en række lignelsestaler for sine disciple og en stor folkeskare ved bredden af Galilæas Sø. Den første lignelse handler om sædemanden, der engang gik ud for at så: Nogle af kornene falder på vejen, hvor de ædes op af fugle; andre lander på en klippegrund med meget lidt jord og slår ikke rod; atter andre falder blandt tidsler og kvæles. Nogle sædekorn falder dog også i god jord og bærer frugt - "i tredive og tres og hundrede fold." "Den, der har ører at høre med, skal høre!", lyder moralen til sidst (Mark. 4, 3-9).

Meningen med denne tale er ikke umiddelbart klar, og på afstand af skaren udspørger disciplene derfor Jesus om lignelsens betydning. "Til jer er Guds riges hemmelighed givet", svarer han først, "men til dem udenfor kommer alt i lignelser." Indsigt i Gudsrigets hemmelighed - dets mysterion - er åbenbart forholdt den store skare uden for inderkredsen og forbeholdt "hans ledsagere og de tolv" (Mark. 4, 10-11).

"Forstår I ikke denne lignelse?", siger Jesus nu og udlægger, at "sædemanden sår ordet" - sår logos: Kornene på vejen svarer til de mennesker, fra hvem Satan straks borttager dette ord, så snart de har hørt det, mens såsæden på klippegrunden er et billede på dem, som først tager imod ordet med glæde, men ikke lader det slå rod i sig. Kornene, der falder blandt tidsler, symboliserer dem, som har hørt ordet, men hvis verdslige bekymringer og begær efter rigdom kvæler det, så det ikke bærer frugt. Frugt bærer nemlig kun de, som både hører og modtager ordet - ligesom når såsæden falder i god jord (Mark 4, 13-20).

Billedplanet i lignelsen afspejler givetvis den galilæiske bondes erfaringsverden, og den kognitive pointe vækker genklang af Jonien:

Skønt denne logos virkelig eksisterer, forstår menneskene den aldrig, hverken før eller efter de har hørt om den; for selvom alt foregår i overensstemmelse med logos, ligner de uprøvede personer, selv når de efterprøver sådanne ord og handlinger, som jeg beskriver, idet jeg inddeler hver enkelt ting i overensstemmelse med dens natur og forklarer, hvordan den er. (af: DK 1$)^{1}$

Ligesom Jesus betoner også Heraklit en auditivt funderet erkendelse af logos (DK 50), hvis fysiske eksponent i hans tilfælde er ild: "Lynet [keraunos: Zeus' tordenkile] styrer alt" (DK 64) inden for en verdensorden, hvor "solen er ny hver dag" (DK 6), og lyset dog "aldrig går ned" (DK 16). For ildens guddom er på én gang 
[...] dag og nat, vinter og sommer, krig og fred, mæthed og sult. Han forandrer sig på samme måde som ild, der, når den blandes med røgelsesstoffer, får navn efter hver enkelts duft. (DK 67)

Tilsvarende sammenligner Jesus i endnu en 'vækstlignelse' Guds rige med en mand, der har tilsået sin jord og "sover og står op, nat og dag", mens kornet "af sig selv" (automate) giver afgrøde: "først strå, så aks, så fuld kerne i akset." (Mark. 4, 26-28).

Guddommeligheden identificeres således hos både Jesus og Heraklit med naturens 'hændelse' qua fysis - med selve det at vokse og gro. Gudsriget er som et sennepsfrø, siger Jesus: Det er først det mindste af alt, men vokser så op til et træ med så store grene, at himlens fugle bygger rede i dets skygge (Mark. 4, 30-32). Denne "eneste sande klogskab", som Heraklit kalder guddommen, der både "vil og vil ikke benævnes med navnet 'Zeus"' (DK 32), fordi den på den ene side nok er guddommelig, men på den anden side hverken opfattes personligt eller fremtræder $i$ en fastafgrænset form. I lighed med såsædens vækst i det galilæiske landskab, men til forskel fra den skinnende hvide Kristus oppe på bjerget, som udpeges for disciplene af en røst fra skyen - "Det er min elskede søn. Hør ham!" (Mark. 9, 7) - og hermed fikseres i sin uniforme hvidhed som netop det guddommelige.

I modsætning til transformationens statisk anskuede Kristusfigur afspejler Jesu lignelsestaler altså en forandringspræget og naturbunden forståelseshorisont. Det kan derfor næppe undre, at Sædemandslignelsen allerede i Det Nye Testamentes ældste evangelium bliver udlagt som et mysterion, ligesom også Heraklit allerede i antikken blev opfattet som så gådefuld, at han fik tilnavnet 'den dunkle'. "Heraklit siger vel", forsøger Sokrates sig i Platons Kratylos, "at alt er i bevægelse [panta korei] og intet i ro; og han sammenligner tilværelsens fænomener med en flodstrøm, idet han siger: "Man kan ikke to gange gå ned i den samme flod."' (DK A 6; Krat. 402a). En tolkning, der muligvis ligger til grund for det berømte dictum 'alting flyder' - panta rei - som imidlertid groft forenkler læren om forandring. For "Mens det forandrer sig, hviler det ud." (DK 84a).

Problemet lader for både Platon og evangelisten i denne sammenhæng til at være, at hvis alting konstant forandres, kan man foranlediges til at slutte, at der intet konstant er i verden. Og hvis der intet konstant er, så kan der i yderste konsekvens heller intet sprog være og derfor ingen tænkning. Tanken om en absolut forandringstilstand bliver derved ligeså selvdestruktiv som destruktiv for troen på en uforanderlig Gud, ligesom også påstanden om, at man ikke kan gå ned i den samme flod to gange, medfører en negation af begrebet 'flod'. 
Man bør derfor skelne mellem et "mikrosprog" og et "makrosprog", pointerer Hartnack i en kantiansk inspireret analyse af flodbilledet: Siger man f.eks., at floden ikke var den samme i dag som i går - den var koldere og mere snavset - er dette en sætning i mikrosproget. Hævder man derimod at have svømmet i den samme flod i årevis, så taler man i makrosproget, hvor en tings identitet med sig selv fremsættes. Tanken om en "fuldstændig heraklitisk tilstand" - en tilstand beskrevet i mikrosproget, hvor alt konstant forandres - ville her være et brud på den dybde-grammatiske regel, at der i enhver forandringsproces er et forandringens subjekt, som forbliver uforandret. Nemlig den flod, der fortsat består, selvom vandet på overfladen forandrer sig konstant (Hartnack 1996: 19).

Udlægningen af Sædemandslignelsen - "Sædemanden sår logos" - er et muligt eksempel fra den kristne Bibel på opdagelsen af en sådan dybde-grammatisk regel. Det sker kun sjældent (og kun denne ene gang i Lignelseskapitlet), at Jesus forklarer meningen med sine lignelser, og der kan derfor meget vel være tale om en tilføjelse fra evangelistens egen hånd - en såkaldt interpolation. En antagelse, der virker plausibel set i lyset af det forhold, at det må have været sin sag at transcendere det empiriske inden for rammerne af nogle overleverede fortællinger - de mundtlige og/eller skriftlige kilder til Jesus, som Markusevangeliet er (delvist) baseret på - hvor de med Gudsriget lignede fænomener forandres konstant: Transformationens Kristus-vision ville være malplaceret hér. Men evangelisten kan uddrage denne foreløbigt meningsgivende og netop dybde-grammatiske regel af lignelsen, at logos er immanent i såsædens vækst.

Markus synes hermed at nære den samme tiltro som Hartnack til, at en begrebslig analyse af dagligsproglige udtryk er nøglen til at løse eller opløse filosofiske problemer. Det, der skal analyseres i et filosofisk udsagn, er ifølge Hartnack ikke troværdigheden af en given vision, men derimod om der foreligger brud på sprogets logiske struktur. Det er her filosofiens opgave, mener han, forsat at opdage de nødvendige dybde-grammatiske regler, foruden hvilke det ville føre til sprogets og tankens kollaps (Hartnack 1996: 12-13). "Forstår I ikke denne lignelse?", spørger Jesus sine disciple hos Markus inden udlægningen af såsædens vækst som et billede på logos: "Hvordan skal I så kunne forstå de andre lignelser?" (Mark. 4, 13).

Læst i denne optik er der altså på ét niveau i såvel den joniske flods strømmende vande som i den galilæiske marks spirende vækst et subjekt, der forbliver uforandret, selvom floden og marken på et andet niveau konstant forandrer sig. Nemlig forandringens subjekt, som både Jesus (eller Markus) og Heraklit kalder for logos. "Mens det forandrer sig, hviler det ud", kan Heraklit derfor netop konstatere: 'Det er trættende at arbejde for og blive behersket af 
de samme [: former?]." (DK 84a+b). "Af sig selv giver jorden afgrøde", siger Jesus: "Men når kornet er modent, går han [: manden, der har tilsået sin jord] straks i gang med seglen, for høsten er inde." (Mark. 4, 28-29).

\section{Paradise Lost}

Jeg fremlagde indledningsvis den tese - min anden tese - at forholdet mellem natur og ånd, der syner harmonisk i Jesu lignelser, erfares som modsatningsfyldt ved Lignelseskapitlets afslutning, hvilket afføder angst blandt Jesu disciple. Med 'angst' mener jeg i denne sammenhæng en tilstand eller stemning beslægtet med den, Kierkegaard i Begrebet Angest definerer som

[...] noget aldeles forskjelligt fra Frygt og lignende Begreber, der referere sig til noget bestemt, medens Angest er Frihedens Virkelighed som Mulighed for Muligheden. (SKS 4: 348)

På trods af det faktum, at begrebet angst endnu ikke findes i hverken det klassiske eller det bibelgræske sprog, vil jeg altså hævde, at den 'eksistentielle angst' findes tematiseret allerede længe før Augustin, hvis Bekendelser fra slutningen af det fjerde århundrede e.Kr. ofte forbindes med angstens gennembrud i litteraturen. Nemlig i fortællingen om stormen på Galilæas Sø i Mark. 4, 35-41.

Sandsynligvis via de latinske ord angor, 'uro', og anxietas, 'ængstelighed', har det danske angst - ligesom det tyske Angst, det engelske anxiety, det franske angoisse m.fl. - rødder i det oldgræske verbum angko, hvis aktive betydning er 'tilsnører' eller 'kvæler'. F.eks. i skildringen i Homers Iliade (ca. 800 f.Kr.) af duellen mellem Prins Paris og Kong Menelaos ved Troja:

Og den broderede rem, der holdt hjelmen spændt under hagen, snæred sig ind i det bløde af halsen og kvalte [angke] ham næsten.

(Il. 3, 371-372)

Anvendt i sin såkaldte mediale diatese (genus verbi), der på græsk bruges om handlingsformen mellem den aktive og den passive, forekommer verbet bl.a. hos lægen Hippokrates (f. ca. 460 f.Kr.) i beskrivelsen af den alvorligt febersyge patient, der er ved at kvæles i sin egen sygdom (Morb. 2, 68). I passiv kan det betyde 'bliver druknet', som når digteren Theokrit (f. ca. 310 f.Kr.) fortæller, hvordan ulykker ifølge gammel overtro kan afværges med en spytklat (Theoc. 7, 125). Etymologien viser således, at verbalstammen angk- oprindeligt blev forbundet med vejrtrækningsproblemer af forskellig art. Et senere veldokumenteret symptom på angsten, hvilket givetvis har ligget til grund for 
begrebsdannelsen angkos, 'angst', i det senere græske sprog. ${ }^{2}$

Allerede i sine ældst overleverede former adskiller verbet angko sig altså betydningsmæssigt fra verbet fobeo, 'frygter', der ligesom substantivet fobos, 'frygt', normalt refererer til noget helt konkret i form af f.eks. en faretruende genstand. I en original sprogkonstruktion og med en noget forskudt betydning til følge finder både fobeo og fobos dog også anvendelse i Markus' beskrivelse af stemningen blandt Jesu disciple, da den sidste lignelse er blevet fremlagt for dem og folkeskaren ved bredden af Galilæas Sø.

"Lad os tage over til den anden bred", har Jesus sagt "samme dag, da det blev aften", og han er blevet alene med disciplene. De sejler ud på søen, men støder ind i en voldsom hvirvelstorm, hvorunder båden er "lige ved at fyldes" med vand. Disciplene må derfor vække Jesus, der upåvirket "lå i agterstavnen og sov på en hynde." "Mester, er du ligeglad med, at vi går under?", spørger de, hvorpå han rejser sig op, truer ad stormen og siger til søen: "Ti stille, hold inde!" Da lægger stormen sig, og det bliver "helt blikstille" (Mark. 4, 35-39).

$\mathrm{Nu}$ går Jesus i rette med disciplene for deres mangel på tro i en passage, der former afslutningen på Mark. 4. Den danske bibeloversættelse læser:

"Hvorfor er I bange? Har I endnu ikke tro?" Og de blev grebet af stor frygt og sagde til hinanden: "Hvem er dog han, siden både storm og sø adlyder ham?" (Mark. 4, 40-41)

"De blev grebet af frygt for stor frygl" kan den tredje sætning mere præcist oversættes fra det græske "efobethesan fobon megan", hvor den passive datidsform af verbet fobeo i tredje person pluralis - efobethesan: "de blev grebet af frygt" - knyttes an til fobon megan: "stor frygt". Stemningen fortættes altså fra "bange" til grebethed af "frygt for stor frygt" i stilheden efter stormen ved antydningen af et fravar af tro.

At fortællingen om stormen i den forbindelse handler om overskridelsen af en kognitiv grænselinje i discipelgruppen er allerede blevet indikeret flere gange $\mathrm{i}$ det foregående. For det første ved opfordringen til at "tage over til den anden bred", da dagen for lignelsestalerne svinder hen. Og for det andet ved kontrasteringen af den oprejste Betvinger af stormen med den Jesus, der umiddelbart forinden "sov på en hynde" i agterstavnen. Til forskel fra lignelsestalernes sædemand, der i en tilsyneladende uafbrudt flydende cyklus "sover og står op, nat og dag", markeres det nu eksplicit, at disciplene vakkede Jesus, inden han rejser sig.

Markus synes hermed at anslå det samme tema, som Kierkegaard udfolder i Begrebet Angest vedrørende det forhold, at "Forskjellen mellem mig selv og mit Andet" først sættes "vaagen" - "sovende er den suspenderet, drømmende 
er den et antydet Intet." (SKS 4: 347). 'Ti stille, hold inde!", siger Jesus til søen, da han rejser sig, og evangelisten skaber hermed den europæiske litteraturs måske første billedlige udtryk for den brydningsflade, Kierkegaard kalder for "Øieblikket" og definerer som netop et "billedligt Udtryk". Et udtryk for "Evighedens første Reflex i Tiden, dens første Forsøg på ligesom at standse Tiden":

Øieblikket er hiint Tvetydige, hvori Tiden og Evigheden berøre hinanden, og hermed er begrebet Timelighed sat, hvor Tiden bestandig afskærer Evigheden og Evigheden bestandig gjennemtrænger Tiden. Først nu faaer hin omtalte Inddeling sin Betydning: den nærværende Tid, den forbigangne Tid, den tilkommende Tid. (SKS 4: 392)

Så længe øjeblikket ikke er indtruffet, er forskellen mellem tid og evighed heller ikke, eller den er blot "discrimen", et skel, der ikke opleves som egentlig modsætningsfyldt. Det evige viser sig som den mulige, men endnu ikke virkeliggjorte ånd - som et "Incognito", siger Kierkegaard; et "hvem" spørger disciplene til hos Markus. Det hævdes i Begrebet Angest, at forskellen mellem tid og evighed oprindeligt tilsløres af "Skjønheden", som danner en syntese mellem sjæl og legeme, hvor ånden er udelukket eller "drømmende" i mennesket. En skønhed, der nemlig skjuler modsigelsen mellem det sjælelige og det legemliges hhv. evige og tidslige aspekt, hvis blotlæggelse forudsætter den opvågnende ånds adskillende gennemboring af enheden af kød og drømmende ånd. Derved konstitueres en ny syntese af sjæl og legeme i "vaagen" ånd, og "Forskjellen mellem mig selv og mit Andet" er sat (SKS 4: 394; 369; 347).

Som et eksempel på den første syntese peger Kierkegaard på græciteten, der endnu var præget af den samme uskyldige uvidenhed som mennesket før Syndefaldet. I denne tilstand er der for så vidt "Fred og Hvile", men der er dog også "noget Andet" - erfaringen af et fravar - eftersom ånden konstant viser sig som en fristende skikkelse, der på én gang "frister dens Mulighed" og samtidig "er borte saa snart den griber efter den, og er et Intet, der kun kan ængste." (SKS 4: 392; 347-348).

Angsten bærer på denne måde hos Kierkegaard - og på lignende vis også hos Markus - vidnesbyrd om et urealiseret åndeligt potentiale, der navnløst anes gennem en drømmeagtig uro, som varsler opbrud og forandring. Angsten er derfor også potentielt konstruktiv og en i sidste ende mennesket dannende faktor. "Angesten bliver ham en tjenende Aand", siger Kierkegaard, "der mod hans Villie fører ham, hvorhen han vil." F.eks. kan man "ved Angesten dannes til Troen", idet angsten "øieblikkelig" sætter uendelighedens trumf i endeligheden (SKS 4: 457-458). 
Det er en tilsvarende trumf, forekommer det, Markus så at sige sætter i discipelgruppen ved udsejlingen fra sædemandens verden til hav. En verden, der - med Kierkegaards karakteristik af græciteten - er funderet i "Naturens tilsyneladende trygge Bestaaen i Tiden", hvor tid og evighed opfattes lige abstrakt, og tiden derfor ingen reel betydning har. For først i øjeblikket sættes skellet mellem den nærværende tid, den forbigangne tid og den tilkommende tid. (SKS 4: 391-392). Præcis som Jesu passificering af stormen i fortællingens skelsættende øjeblik blotlægger kontrasten mellem 'nu', 'før' og 'efter': mellem opvågnende ånd, cyklisk 'naturtid' og troen, der skal, men endnu ikke kan 'haves'.

Selv finder Kierkegaard også "en poetisk Omskrivelse af Øieblikket" i Det Nye Testamente - i Paulus' tale om verdens undergang:

Vi skal ikke alle sove hen, men vi skal alle forvandles, i ét nu, på et øjeblik, ved den sidste basun; for basunen skal lyde, og de døde skal opstå som uforgængelige, og vi skal forvandles. For dette forgængelige skal iklædes uforgængelighed, og dette dødelige skal iklædes udødelighed. (1. Kor. 15, 51-53)

Undergangsøjeblikket bliver hermed "commensurabelt for Evigheden", mener Kierkegaard, fordi dette "i samme Øieblik udtrykker Evigheden." Ligesom da tvende københavnske kunstnere engang under den mimiske fremstilling af "en eller anden lidenskabelig Conflikt" indimellem pludselig brød af og stod som forstenede over for hinanden i det øjeblikkelige mimiske udtryk (SKS 4: 391).

På en lignende måde iscenesættes undergangsøjeblikket i Mark. 4 for den (erfarings)verden, der skildres i lignelserne: Evangelisten fastfryser - stilistisk såvel som kognitivt - discipelgruppens plastisk spørgende "hvem" i kapitlets sidste sætning, der får lov at stå ubesvaret helt frem til Peters konstatering "Du er Kristus" i Mark. 8. Det plastiskes virkning i øjeblikkets fastfrosne 'nu' beror ifølge Kierkegaard på, at det evige udtryk er udtrykt netop evigt, akkurat som det land, Jesus og disciplene sejler bort fra, i ét nu for altid er tabt. Også selvom skibet i Mark. 5 igen går både frem og tilbage over Galilæas Sø.

\section{Brud og opbrud}

Betvingelsen af stormen resulterer altså i den angstfremkaldende erfaring blandt disciplene, at mennesket Jesus rummer en verdensoverskridende kraft. Et paradoks, der tilsyneladende er frembragt af et brud på den dybde-grammatiske regel, som Markus ovenfor blev hævdet at opdage i tydningen af såsædens vækst som et billede på logos. En regel, han nu imidlertid synes at ophave, 
for så vidt som det imperative "'Ti stille, hold inde!" differentierer det guddommelige fra bevægelsens element, naturen. Det guddommelige modsvarer nu ikke længere det sansbare lys, der - som Heraklit sagde om solen - aldrig ville vige sin fastlagte bane. Så skulle Dikes hævngudinder nok finde frem til den (DK 94).

Paradokser er advarselstegn, siger Hartnack om de brud på sprogets logik, der medfører en negation af floden, hvori man badede i går (Hartnack 1996: 11). Men hvordan kan man undgå brud på sprogets logiske struktur i en fortælling, der anticiperer det sammenstød inden for senere kristen tænkning mellem modsatrettede synspunkter, der udelukker hinanden og sprænger al jordbunden fornuft i fordringen på en lidenskabelig, absurd tro?

Man kan ikke undgå sådanne brud, viser afslutningen på Mark. 4, for til forskel fra Hartnacks opfattelse af paradokserne udspringer fortællingen om stormen på søen ikke af en uigennemtænkt idé. Snarere tværtimod, idet medtænkningen af disciplenes "frygt for stor frygt" vidner om evangelistens kendskab til den potentielle reaktion på paradokset: til at angsten går hånd $\mathrm{i}$ hånd med radikalt erfarede brud på sprogets dybde-grammatiske regler. Også Kierkegaard forbinder angsten med "et gaadefuldt Ord" - et ord, som deler det, der før var ét. Ligesom da Gud forbød Adam at spise af træet til kundskab om godt og ondt og netop derved lod ham ane denne differens sammen med den ængstende mulighed af selv at kunne (SKS 4: 350).

I lighed med Kierkegaards opfattelse af angsten som "Troens Anticipation" og af troen som frelsende ved angsten, jf. sidste kapitel af Begrebet Angest, indikeres sidst i Mark. 4 forfatterens tillid til troen som det frelsende aspekt. Til forskel fra Kierkegaard har Markus til sin tematisering af angsten imidlertid ikke haft adgang til et dækkende ord herfor i datidens græske vokabular. Han må derfor overskride begrebet fobos' iboende muligheder ved kontekstuelt at sprænge dets grænser. For på trods af den ro, som lægger sig over vandet efter stormen, er der fortsat 'noget andet', der glimrer på søen. Nemlig det fravær, hvis psykologiske udslag først et senere græsk sprog satte på begreb og definerede som angkos, angst.

Fortællingen om stormen på Galilæas Sø er således også fortællingen om 'angstbegrebets førbegrebslige genese', foranlediget af et erfaret modsætningsforhold mellem natur og ånd. En modsætning, der dog endnu ikke har manifesteret sig i en tilsvarende differens mellem krop og sjæl, som senere bliver så problematisk for bl.a. Augustin. Faktisk bruges ordene 'krop' (soma) og 'sjæl' (psykee) kun én gang hver i hele Markusevangeliet: dels om Jesu døde krop efter korsfæstelsen (Mark. 15, 44); dels bekender Jesus, da Judas' forråelse nærmer sig, at "min sjæl er fortvivlet til døden." (Mark. 14, 34). Det er altså først "i Synthesens yderste Spidse", som Kierkegaard kalder dødsøjeblikket i Begrebet 
Angest, at begreberne 'krop' og 'sjæl' finder anvendelse hos Markus, der dog ikke udfolder denne distinktion.

Endvidere ville det være en overfortolkning af fortællingen at tale om 'subjektivitetens fødsel' i litteraturen. Der ville derved blive tale om den samme væsensforvandling af "det Skjebnesvangre" i individet, som Kierkegaard påpeger under henvisning til senere tiders forfejlede tolkninger af de græske tragedier, hvorefter helten selv skulle have valgt sin skæbne. Men noget sådant er der ikke på spil - det handler slet ikke om hin enkelte, men om gruppen: om "de" og "dem", som disciplene udelukkende hedder her. (Uden at de dog modsvarer 'mængden' i en kierkegaardsk forstand, hvilket derimod kunne siges om folkeskaren ved bredden af Galilæas Sø).

Jo mere subjektiviteten bliver reflekteret, siger Kierkegaard i Enten-Eller, desto mere etisk bliver skylden. Ikke mindst derfor er det en misforståelse af det tragiske element $i$ tragedien "at lade alt det Skjebnesvangre transsubstantiere sig i Individualitet og Subjectivitet." For man vælter i så fald hele heltens liv på hans skuldre som hans egen gerning, men derved forvandler man også hans æstetiske skyld til en etisk (SKS 2: 143-144).

Og det er just græcitetens "dybe Hemmelighed", hævdes det i Begrebet Angest, at denne ikke havde noget etisk, men alene et æstetisk begreb om skylden. En iagttagelse, der udmærket lader sig applicere på det forhold, at mens angsten er personligt reflekteret hos Augustin, så fremstilles den som en kollektiv tilstand $\mathrm{i}$ discipelgruppen. En tilstand, der netop implicerer en æstetisk skyld, hvis man forstår 'æstetisk' på græsk som aisthesis, 'fornemmelse', og 'skyld' i relation til det forskyldte efter udsejlingen fra fastland til hav.

Selvom angsten ikke er genereret af en selvreflekterende subjektivitet, må den tidligste kristendom altså alligevel forholde sig til en fundamental differens, der ligesom kiler sig ind mellem natur og ånd. En differens, der ikke kan spores i Jesu lignelsestaler, men som til gengæld viser sig tydeligt i Markus' skildring af stormen på Galilæas Sø. Her bliver det på den anden side vanskeligt at få øje på det sennepstræ, hvis konturer endnu kan anes fra agterstavnen, da skibet med den endnu sovende Jesus på hynden stævner ud fra den 'joniske' horisont, hvor naturens lys aldrig går ned. I sin bevarende dvælen ved denne forståelseshorisont indeholder Markusevangeliets korte Lignelseskapitel måske en nøgle til forståelsen af kristendommens mest oprindelige forudsætning. 


\section{IV. 'Jesus-glemsel'}

Fortællingen om stormen udgør det mest markante skæringspunkt i Markusevangeliets divergerende beskrivelser af det guddommeliges væsen og form: Historien indrammer undergangsøjeblikket for menneskets lyttende tilnærmelse til en ikke visuelt fikserbar guddommelighed, der lignes med naturbegivenhedens forandringsprægede dynamik. Nu betones i stedet en beskuen af det guddommelige i en statisk form et sted 'meta' - trans - fysis.

Det må følgelig kunne konkluderes, at Markus har opfattet Kristus-visionen skildret i Mark. 9 som uforenelig med det element, der bærer og nærer såsædens vækst skildret i Mark. 4. Ligesom også den heraklitiske lære om fysis og logos som ét viste sig uforenelig med den platoniske theoria. Evangelisten lader hermed til at have forholdt sig på samme måde til lignelserne, som den græske idealisme forholdt sig den indsigt, filosofien ifølge Heidegger har 'glemt'. Og $\operatorname{dog}$

[...] én gang, ved den vesterlandske tænknings begyndelse, lynede sprogets væsen i lyset af væren. Én gang, da Heraklit tænkte logos som nøgleord, for i dette ord at tænke det værendes væren. Men lynet slukkedes brat. Ingen begreb dets stråle og nærværet af, hvad den oplyste. (GA 7:233)

Den ældste vesterlandske tænkning hviler i glemsel, siger Heidegger - den øser af glemslen og lægger det frem, som er henlagt heri. Allerede den med Heraklit omtrent samtidige Parmenides grundlægger imidlertid den værensglemsel, hvor ét værende sættes som det hojeste. Parmenides, hedder det i et essay med titlen "Moira" efter navnet på den græske skæbnegudinde, indleder den egentlige filosoferen på Hegels facon, begrebslogikken, men han mangler dialektikken, som Hegel finder hos Heraklit. Parmenides har nemlig modtaget sin sandhed som en åbenbaring fra Moira, der har bundet det værende fast, så det kan være "helt og ubevægeligt" (DK 8, 38). Derved bliver det værende til eidos og idea - vision - og vejen banes for den forestilling i filosofien, at sandheden er genstand for tanken (GA 7: 241-243; 257).

Fra og med udlægningen af det værende som idea, anfører Heidegger i Platons Lehre von der Wahrheit, bliver idéen sandhedens muliggørende grund. Tingenes højeste og første årsag bliver endvidere - hos både Platon og Aristoteles - bestemt som det guddommelige, hvorved metafysikken fra begyndelsen bliver teologisk: Det værendes årsag identificeres med Gud, og lyset fra væren forlægges så at sige i netop denne årsag (Plat.: 46-48).

Skulle man ud over dikotomiseringen af natur og ånd pege på en videre konsekvens af den kristne traditions lignende tendens, må det først og fremmest være negligeringen af tanken om en umiddelbart givet frelse ved visdom til fordel 
for en af tro og gerninger betinget frelse af nade. Forestiller man sig, at den tradition, der kommer til udtryk i Jesu lignelser, havde fået en mere fremtrædende plads i den senere kristendom, så havde denne religion givetvis formet sig ud fra nogle helt andre værdier. Værdier, den kristne kirke fra begyndelsen har bekæmpet indædt under fællesnavnet 'gnosticisme', men som dog endnu synes at møde en vis anerkendelse hos Markus, hvor ordet 'nåde' i øvrigt ikke forekommer. For selvom lignelseskonteksten er uanvendelig som ramme for Kristus-visionen, kan evangelisten ikke tænke bort fra denne kontekst uden at medtænke erfaringen af "frygt for stor frygt". Her taler ordene i Hölderlins digt Die Wanderung fra 1802:

Svært forlader, hvad nær oprindelsen bor, stedet.

Hvad der endnu står ubesvaret er spørgsmålet om årsagen til kristendommens 'Jesus-glemsel', som man med en omskrivning af Heidegger kunne tale om her. Skildringen af disciplenes reaktion under forklarelsen på bjerget peger på det guddommeliges indplacering i en rumlig topos som en mulig foranledning hertil:

I forbindelse med transformationen viser de jødiske profeter Elias og Moses sig for disciplene i samtale med Jesus, og den forfærdede Peter, som ikke aner, hvad han skal sige, foreslår, at de bygger tre hytter - én til hver. Før nogen kan nå at svare, overskygges begge profeterne imidlertid af skyen, hvorfra Gud udråber Jesus som sin søn. Ved således at lade Jahves udvalgte mænd forsvinde ud af historien, ligeså hurtigt som de dukkede op, kan Markus distancere sin Kristusfigur fra den jødiske tanke om Guds møde med mennesket i en principielt uanskuelig væren: Israels Gud er den, som ER, men dog kun vil tilkendegive sit 'væsen' i skikkelse af f.eks. en brændende tornebusk (Ex. 3, 1 f.) eller lade sig "se fra ryggen", som Herren siger til Moses: "Mit ansigt må ingen se." (Ex. 33, 23).

I overensstemmelse med god platonisme ligger det derimod lige for hos Markus, at det guddommelige må indsættes til beskuelse i et klart defineret rum. Dette er disciplene allerede blevet gjort bekendte med under Jesu første helbredelsesundere, der finder sted i skiftevis husenes og synagogernes arkitektoniske rum (Mark. 1, 29-34; 2, 1-12 o. fl. st.). Huset bliver senere også stedet for den nadverindstiftelse, der helt skal afløse den jødiske tempelinstitution (Mark. 14, 12-25).

Imperativen hor i proklamationen "Det er min elskede søn. Hør ham!" viser, at det auditive aspekt ikke uden videre afskrives af Markus. Men det udskrives af en kontekst, hvor øret altid er givet hen til noget andet, som det selvsagt ikke er disponeret for at kunne overskue. Af muligvis samme årsag opgav alle- 
rede Platon efterhånden den sokratiske dialog, der ofte stillede flere spørgsmål end den besvarede, til fordel for en teoretisering over det guddommelige ved hjælp af metaforer, som knytter sig til rummet. Derfor opfattes lignelserne allerede i det ældste evangelium som et mysterion, og derfor hed Heraklit allerede i antikken 'den dunkle'. "Hvordan kan nogen undgå det [: lys] der aldrig går ned.", spørger han ellers (DK 16). "For han udtaler det Lysende [das Lichtende]", bemærker Heidegger indledningsvis i et foredrag om Heraklit, "idet han forsøger at fremkalde dettes skær i tænkningens sprog." "Han er den dunkle", konkluderes det til slut, "fordi han spørgende tænker i lyset." (GA $7: 265 ; 288)$.

Den spørgen må imidlertid ændre karakter efter demarkationen af fysis, og allerede den tidligste kristendom må i denne sammenhæng forholde sig til Jesu paradoksalt verdensoverskridende kraft. "Endnu er Uskyldigheden”, siger Kierkegaard om tilsynekomsten af den tvedelende magt, han kalder for "Aanden": Endnu befinder mennesket sig mentalt i Edens Have, men der behøver blot at lyde ét ord - det gådefulde ord - "saa er Uvidenheden concentreret", og "Angesten har ligesom faaet sit første Bytte". Også selvom "Adam egentlig ikke forstod dette Ord" (SKS 4: 350). Ligesom disciplene heller ikke forstår Jesu ord - "Ti stille, hold inde!" - der blotlægger differensen mellem natur og ånd. "Hvem er dog han", må de forståeligt nok spørge, "siden både storm og sø adlyder ham?"

Kaldet bringer det, som kaldes nærmere, siger Heidegger et sted i Unterwegs zur Sprache i forbindelse med udlægningen af en strofe hos digteren Georg Trakl om aftenklokken, der klinger gennem sneen. Dog dvæler dette kaldte endnu fjernt, fordi snefaldet bringer menneskene ud under den mørknende himmel, og tonerne fra klokken bringer dem frem som dødelige for det guddommelige.

\footnotetext{
Noter

${ }^{1}$ DK = Diels \& Kranz: Die Fragmente der Vorsokratiker. Jeg citerer efter Jørgen Mejers oversættelse af de græske fragmenter.

${ }^{2}$ Et leksikon over det moderne græske sprog (Lexiko Tis Neas Ellinikis Glossas, 1998) bestemmer bl.a. angkos som "noget, der viser sig som en ængstelig forventning om et forestående onde, om fare eller om en generelt ubehagelig tilstand, og som har særlige fysiske eller adfærdsmæssige kendetegn.” Præcis hvornår og under hvilke omstændigheder ordet angkos kommer ind i sproget, vil det kræve en nærmere undersøgelse at afklare.
} 


\section{Litteratur}

Augustin (1998): Augustins Bekendelser, København: Sankt Ansgars Forlag.

Babiotis, Georgiou D. (red., 1998): Lexiko Tis Neas Ellinikis Glossas, Athen: Kentro Lexikologias.

Biblen: Det gamle Testamente, Det nye Testamente (1992), København: Det Danske Bibelselskab.

Diels, Hermann og Kranz, Walther (red., 1996): Die Fragmente der Vorsokratiker Bd. 1, Zürich: Verlag Weidmann.

Hartnack, Justus (1996): Strejftog i filosofien, Viborg: C.A. Reitzels Forlag.

Heidegger, Martin (1947): Platons Lebre von der Wabrheit, Bern: Verlag A. Francke AG.

Heidegger, Martin (1959): Unterwegs zur Sprache, Gesamtausgabe Bd. 12, Pfullingen: Verlag Günther Neske.

Heidegger, Martin (2000): Vorträge und Aufsäť̨e, Gesamtausgabe Bd. 7, Frankfurt am Main: Vittorio Klostermann Verlag.

Hippokrates (1998): De Morbis, Hippocrates Vol. 5, The Loeb Classical Library, London: William Heinemann og Cambridge, Mass.: Harvard University Press.

Homer (2001): The Iliad Vol. 1, The Loeb Classical Library, Cambridge, Mass: Harvard University Press.

Homer (2002): Homers Iliade, Haslev: Nordisk Forlag.

Hölderlin, Friedrich (1946): Sämtliche Werke Bd. 1, Stuttgart: W. Kohlhammer Verlag.

Kierkegaard, Søren (1997): Begrebet Angest, Søren Kierkegaards Skrifter bd. 4, København: Søren Kierkegaard Forskningscenteret og Gads Forlag.

Kierkegaard, Søren (1997): Enten-Eller, Søren Kierkegaards Skrifter, bd. 2., København: Søren Kierkegaard Forskningscenteret og Gads Forlag.

Mejer, Jørgen (1994): Forsokratiske filosoffer - fra Thales til Heraklit, København: Hans Reitzels Forlag.

Mejer, Jørgen (1995): Forsokratiske filosoffer - fra Parmenides til Demokrit, København: Hans Reitzels Forlag.

Novum Testamentum Graece (1995): Stuttgart: Württembergische Bibelanstalt.

Platon (1997): Faidros, Frederiksberg: Det lille Forlag.

Platon (1992): Staten, Københavns Universitet: Museum Tusculanums Forlag.

Theokrit (1869): Idyllen, Leipzig: Verlag B.G. Teubnert 